\title{
Nagyvárosok forgalomtechnikai eszközeinek szerepe a terrorizmus elleni küzdelemben
}

\section{GÁL Erika ${ }^{1}$}

\begin{abstract}
A tanulmány elsődlegesen a nagyvárosi közúti közlekedés és forgalomtechnikai eszközei, valamint a közúti jármúvel elkövetett terrorcselekmények közötti összefüggéseket, kapcsolatokat teszi vizsgálat tárgyává. Az alapvető fogalmi meghatározások mellett két dimenzióban veszi górcső alá a forgalomtechnika terrorizmus elleni védekezésben is funkcionalitással bíró eszközeit: egyrészt a kiemelten és állandó jelleggel védett objektumok, másrészt pedig a nagyvárosokban ideiglenesen védett helyszínek szemszögéből. Annak érdekében, hogy egy-egy cselekmény elkövetéséhez használt jármúvek jelleg szerinti kategorizálását is elvégezhessük, az elmúlt évek jármútípusra és a terrorcselekmény halálos áldozataira vonatkozó európai statisztikai adatokat is feldolgozzuk. A vizsgálat lefolytatását követöen a tanulmány kísérletet tesz a forgalomtechnika eszközeinek - rendészeti és építészeti szempontokat is figyelembe vevő - szakszerü elhelyezésére, vonatkozó javaslatok megfogalmazására.
\end{abstract}

Kulcsszavak: közúti jármüvek, forgalomtechnikai eszközök, utcabútor, mobil fizikai akadály, terrorcselekmények, objektumvédelem, tömegrendezvények, biztosítószolgálat

\section{Bevezetés}

Habár napjainkban korántsem a nagy, közösségi élet áll hétköznapjaink középpontjában, hiszen a Covid-19-vírus okozta pandémiás időszakban mindennapjainkat saját magunk, családunk, barátaink és mások egészségének védelme érdekében is a szociális távolságtartás hatja át, mégis a jövőbe tekintve vizsgáljuk meg a címben rejlő kérdéseket, problémákat. A rendészeti tevékenység és a terrorizmus kapcsolatát leginkább aszimmetrikus rendészeti kihívásként jellemezhetjük, pontosan úgy, ahogyan a hazai helyzetet vizsgálva tette azt Fehér Zoltán is a kutatásai során. ${ }^{2}$

\footnotetext{
Gál Erika mesteroktató, Nemzeti Közszolgálati Egyetem Rendészettudományi Kar; doktori hallgató, Nemzeti Közszolgálati Egyetem Rendészettudományi Doktori Iskola.

Erika Gál Master Instructor, University of Public Service, Faculty of Law Enforcement; PhD student, University of Public Service Doctoral School of Police Sciences and Law Enforcement.

E-mail: gal.erika@uni-nke.hu, ORCID: https://orcid.org/0000-0003-1676-0381

2 Fehér Zoltán: Gondolatok az aszimmetrikus rendészeti kihívásokról és a lehetséges válaszokról. Hadtudomány, (2015), 1-2. 130-135.
} 
„A terrorizmus és szervezett bűnözés elleni fellépés terén az állami szervek széles körének van feladata e kérdések kezelésében, azonban míg a terrorizmus felderítése, elhárítása fő feladatkörként a Terrorelhárítási Központhoz, addig a szervezett bűnözés kezelése elsődlegesen az általános rendőri feladatokat ellátó rendőri szervezet speciális egységeihez tartozik [...] a terrorizmus elleni fellépés megoldása 43\%-ban politikai, 40\%-ban rendészeti és 7\%-ban katonai beavatkozás eredményeképpen, 10\%-ban pedig "magától « oldódik meg." 3

A fenti százalékos adatok közül a rendészeti tevékenység szerepét tükröző 40\%-os arányt szükséges tovább bontanunk, ugyanis a jelen tanulmány célja elsősorban a nyílt, mindenki számára egyértelműen látható és ezáltal védelmi funkcióját is felfedő, a közterületeken félreérthetetlenül megjelenő rendészeti tevékenységhez kapcsolódó eszközök bemutatása. A kérdés az, hogy a különféle, nagy tömegeket vonzó és azok befogadására alkalmas területek, helyszínek, épületek, események mint a terrorcselekmények esetleges puha célpontjai milyen eszközökkel és milyen hatásfokkal védhetők a nyílt, közterületi rendőri tevékenység és a forgalomtechnikai eszközök által. A fenti fellépési eloszlásból mekkora részt vállalnak a tömegrendezvényeken szolgálatot teljesítő egyes rendőrök, speciális szolgálati csoportok tevékenységét előkészítő, annak tervezését végző, az események során szervezési és dinamikus kockázatelemzést is végző szervezeti egységek? Mindezen kérdések teljes körű megválaszolásához hosszú út vezet, a válaszok felderítését első lépésként a bárki számára nyitva álló területeken fellelhető, építészeti vagy kifejezetten rendészeti célból, vagy e két funkciót egyesítő bűnmegelőzési célú eszközök, valamint a közterületi járőr vagy egyéb sajátos szolgálatok kapcsolatának vizsgálatával kezdem meg. A vizsgálat elsősorban a nagyvárosi tömegrendezvények megtartására alkalmas helyszíneken alkalmazott vagy alkalmazható forgalomtechnikai eszközök, valamint az őrzés-védelem, biztosítószolgálat mint rendészeti taktikai eljárások kapcsolatára fókuszál.

\section{Jármúvek és terrorcselekmények relációja}

Ahhoz, hogy a bevezetőben megjelenített összefüggések vizsgálhatók, magyarázhatók legyenek, mindenféleképpen szükséges bizonyos fogalmak tisztázása, egyértelművé tétele. Így jelen vizsgálati körülmények között a közúti járművek definiálása elengedhetetlen.

Az ember-jármü-környezet, mint a közlekedés hármas egységéből, a jármű elemre kell elsőként koncentrálni. Úgy, ahogyan a hazai szabályozásban is természetszerűen megjelenik: „Jármű: közúti szállító- vagy vontató eszköz, ideértve az önjáró vagy vontatott munkagépet is."4 A jármü fogalmát tovább bontva a beépí-

Fehér (2015) i. m. 130-131.

1/1975. (II. 5.) KPM-BM együttes rendelet a közúti közlekedés szabályairól 1. sz. függelék II. a közúti jármúvekkel kapcsolatos fogalmak a) pont. 
tett erőgéppel meghajtott gépjárművek ${ }^{5}$ és gépkocsik, ${ }^{6}$ azon belül pedig a személyszállítás és a teherszállítás céljából készült személygépkocsik és tehergépkocsik ${ }^{7}$ különíthetők el. Rendészettudományi aspektusból megvizsgálva azonban már tágabb, részletesebb definíciókat találunk, hiszen például a jármű fogalma alatt „a közúti forgalomban való használatra szánt, legalább négy kerékkel rendelkező, 25 km/h-t meghaladó legnagyobb tervezési sebességú gépjármű, valamint pótkocsija, kivéve a síneken futó jármúvet, a mozgó munkagépet, valamint a veszélyes áru szállításakor legfeljebb $40 \mathrm{~km} / \mathrm{h}$ sebességgel közlekedő mezőgazdasági és erdészeti vontatót" ${ }^{8}$ is értjük.

A kutatás másik fő tárgya a terrorcselekmény, amelynek járművekkel való kapcsolata napjainkban már nyilvánvaló, mivel a terrorizmus eszközeként már jó pár évvel ezelőtt megjelent.

A terrorcselekmény „azon nemkívánatos esemény, cselekmény, amikor valaki állami szervet, más államot, nemzetközi szervezetet arra kényszerít, hogy valamit tegyen, ne tegyen vagy eltűrjön, illetve amikor az illető más állam alkotmányos, társadalmi vagy gazdasági rendjét megváltoztatja, megzavarja, lakosságát megfélemlíti, nemzetközi szervezet működését zavarja, meghatározott személy ellen erőszakos, közveszélyt okozó vagy fegyverrel kapcsolatos bűncselekményt követ el”. ${ }^{9}$

Jól látható, hogy az idézett fogalom ismertetőjegyei között közvetlenül nem lelhető fel a jármú mint a terrorizmus eszköze, azonban a jármúvekben, és kifejezetten a gépi meghajtású járművekben rejlő kényszerítő, fenyegető erő, azaz az erőszak alkalmazására használhatóság már egyértelmü kapcsolatot mutat.

A két fő alkotórész jellemzőinek rövid áttekintését követően már könnyedén megvilágítható a harmadik elemmel, azaz a helyszínnel való szoros viszonyuk. A jármű mint eszköz, valamint a zavaró, megfélemlítő, működést akadályozó, erőszakos cselekmény mint magatartás - a jármú fizikai megjelenésére, tulajdonságaira is figyelemmel - nagy kiterjedésű, szabadtéri helyszínen találhat egymásra. Ezen „találkozás” hatását, hatékonyságát tekintve pedig egyértelműen a nagy befogadóképességű, mindenki számára szabadon igénybe vehető vagy látogatható, közterületi vagy részben közterületi jellegű helyszínekre szükséges a hangsúlyt helyezni. Ugyanakkor mindenképpen fontos a helyszín mérete tekintetében, hogy gépjármü üzemszerû mozgására elegendő térrel rendelkezzen.

Ennek a jellemzőnek tökéletesen megfelelnek a tömegrendezvények, nagy létszámú látogatót vonzó események helyszínéül szolgáló területek. Tömegrendezvény alatt pedig egyszerűen megfogalmazva „[a]zonos helyen és időben szervezett programszerű összejövetelen jelen lévő nagyszámú emberek csoportját"10 értjük. Ter-

\footnotetext{
1/1975. (II. 5.) KPM-BM együttes rendelet b) pont.

1/1975. (II. 5.) KPM-BM együttes rendelet c) pont.

1/1975. (II. 5.) KPM-BM együttes rendelet d) és i) pontok.

Boda József (főszerk.): Rendészettudományi szaklexikon. Budapest, Dialóg Campus, 2019. 292. jármű címszó.

Boda (föszerk.) (2019) i. m. 559. terrorcselekmény címszó.

- Heves Megyei Kormányhivatal Rendvédelmi Igazgatás tájékoztató felülete. Heves Megyei Kormányhivatal Rendvédelmi Igazgatás tájékoztató felülete: Közbiztonság, tömegkezelés. tájékoztató prezentáció. é. n.
} 
mészetesen az esemény színtere nagymértékben függ annak céljától is, azaz, hogy milyen okból, célból használja egy időben sok ember az adott területet. A tömegrendezvények céljuk, jellegük szempontjából csoportosíthatók, amellyel párhuzamosan a jellemző helyszín, valamint az eseményen részt vevő csoportok összetétele is meghatározható. Egyetértek Kasza Anett különböző szempontok szerinti csoportosításával, amelyek közül a jelleg szerinti kategorizálás a következő: a tömegrendezvények jellegük szerint társadalmi és politikai, egyházi és hitéleti, sport és szórakoztató, kulturális, tudományos és egyéb csoportokba sorolhatók. ${ }^{11}$

Fontos megjegyezni, hogy különféle intézmények, turisztikai létesítmények is nagy számú embertömeg befogadására alkalmasak, így „[v]onzó célponttá teszi őket, hogy közforgalom számára nyitott magánterület jellegüknél fogva, nagy menynyiségű, kevéssé ellenőrzött személy és gépjárműforgalom zajlik bennük, a túlzott és látványos biztonsági intézkedések pedig a vendégekre nézve elrettentő hatást válthatnak ki”. ${ }^{12}$ Azonban a vizsgálati körből természetükből adódóan bizonyos tömegrendezvények mégis kizárhatók, hiszen az esemény jellege megkívánja a speciális létesítmények igénybevételét a rendezvény megtartására. Ilyenek például azok a sportesemények, amelyeket sportlétesítményekben, illetve különféle kulturális, ismeretterjesztő rendezvények, amelyeket egy kifejezetten ilyen célra elkülönített, zárt térben, épületben szerveznek meg.

A jármű, terrorcselekmény és tömegrendezvény helyszíne logikai kapcsolatát mutatja az is, hogy az angol nyelvű szakirodalomban gyakorta használt kifejezés a ramming típusú terrorcselekmény. A ramming összefoglalja mindezt a kapcsolatot, ugyanis lényegében a gépjármú elsődleges használatára mint a terrorista legfontosabb eszközére utal. A támadás során kihasználják a jármű sebességének és tömegének együttesében rejlő pusztító energiákat, amelyeket a helyszínen tartózkodó védtelen személyek ellen irányítanak. A tömegbe gépjárművel történő behajtás és gázolás nem igényel különösebb előkészületeket, alacsony költség- és „terroristakompetencia"-befektetéssel végrehajtható az ilyen jellegű támadás. Pontosan ezen jellemzői okán igencsak nehézkes az ellenük való védekezés. Különösen helytálló ezen kijelentés a hétköznapok gyalogos forgalmában történő elkövetésekre, mert a közúti gépjármúforgalom mindennapjaink szerves része, így természetszerú, hogy az átlag gyalogos nem számít a forgalom irányából kiinduló támadásra, így gyakorlatilag kivédhetetlenné teszi ezek bekövetkezését, ha a támadó elszántsága, akarata rendíthetetlen. A tömegrendezvények, kiemelten védett vagy turisztikai szempontból frekventált épületek esetén azonban már számos hatékony védekezési elgondolással, technikával találkozhatunk, azonban érdemes górcső alá venni ezek

11 Kasza Anett: A fôvárosi metró alkalmazási lehetőségei a tömegrendezvények biztosítása során. Katasztrófavédelmi Szemle, 19. (2012), 4. 23-27.

12 Lippai Zsolt - Thieme-Eső Milán: A szállodák, mint „puha célpontok”. In Közös kihívások - egykor és most: Tanulmánykötet. Budapest, Magyar Rendészettudományi Társaság Vám- és Pénzügyőri Tagozat, 2020. 162. 
megújulási hajlamát is az elkövetési módszerek változásaihoz való alkalmazkodási képesség tekintetében. ${ }^{13}$

\section{Terrorcselekmények Európában, a közúti jármúvek szerepe}

Az elmúlt évek tendenciáit tekintve a terroristahálózatok nemcsak a világ nagyhatalmainak, hanem az Európai Unió (EU) belső biztonságára, valamint az egyes tagállamok állampolgárainak személyes biztonságára is kifejezetten veszélyt jelentenek. E biztonsági fenyegetések elleni harcban az EU bűnüldözési ügynöksége, az Europol is nagy szerepet vállal. Teszi mindezt a biztonságosabb Európáért, valamint a tagállami polgárok érdekében. A szerepvállalás egyik jól megragadható területe, hogy az európai terrorizmusellenes központ koordinálása mellett határokon átnyúló együttműködésre törekszik a terrorizmus elhárításáért küzdő hatóságokkal. 2007 óta az Europol minden évben elkészíti az EU terrorizmus helyzetéről és trendjeiről szóló jelentését (TE-SAT), amelyben többek között részletes áttekintést nyújt az EU területén bekövetkezett terrortámadásokról, terrorcselekményekről, valamint az ilyen jellegű bűncselekményekkel összefüggő hatósági, bírósági tevékenységekről. Az éves TE-SAT-jelentést az EU-tagállamok, illetve a nemzetközi együttmúködés egyéb partnerállamai által szolgáltatott és ellenőrzött adatok alapján az Europol terrorizmus-szakértői csoportja készíti el. Fontos azonban hangsúlyozni, hogy a tagállami adatszolgáltatás „önbevalláson” alapszik, figyelemmel arra, hogy egyes tagállamok terrorcselekménnyé minősítési eljárásának gyakorlata különböző, így a szolgáltatott adatok minősége is változó. A TE-SAT-jelentések jól strukturáltak, a hozzá szorosan kapcsolódó mellékletek statisztikákat tartalmaznak például a meghiúsult vagy más okból sikertelen, illetve a befejezett támadások számára, továbbá a letartóztatások, illetve a bírósági ítéletek, kiszabott büntetések adataira vonatkozóan is. ${ }^{14}$ Jelen tanulmányban szereplő adatok, kimutatások alapjaként kizárólag a 2015-2019 közötti, ötéves időtartamban, a tagállamok által az Europol részére szolgáltatott, illetve más kutatók által rögzített adatokat dolgoztam fel. Tekintettel arra, hogy a tanulmány elsődlegesen a ramming típusú terrorcselekményekre és azok bűnmegelőzési lehetőségeire fókuszál, ezért az adatok másodlagos feldolgozása nemcsak a befejezett, hanem a sikertelen terroresemények adataira is kiterjed. Az alábbi összehasonlító diagram (1. ábra) jól mutatja, hogy a vizsgált öt évben a terrorcselekmények száma hogyan alakult az EU területén, illetve az összesített számadathoz képest, hogyan alakultak a jármúvel mint elkövetési eszközzel végrehajtott terrortámadások.

\footnotetext{
3 Rácz András - Brestyánszki Flóra: A gépjármúvel végrehajtott, ramming típusú terrortámadásokról és a védekezés lehetőségeiről. Nemzet és Biztonság, (2017), 5. 61-69.

14 Europol: EU Terrorism Situation \& Trend Report (TE-SAT) Reviewing the terrorism phenomenon. 2020.
} 


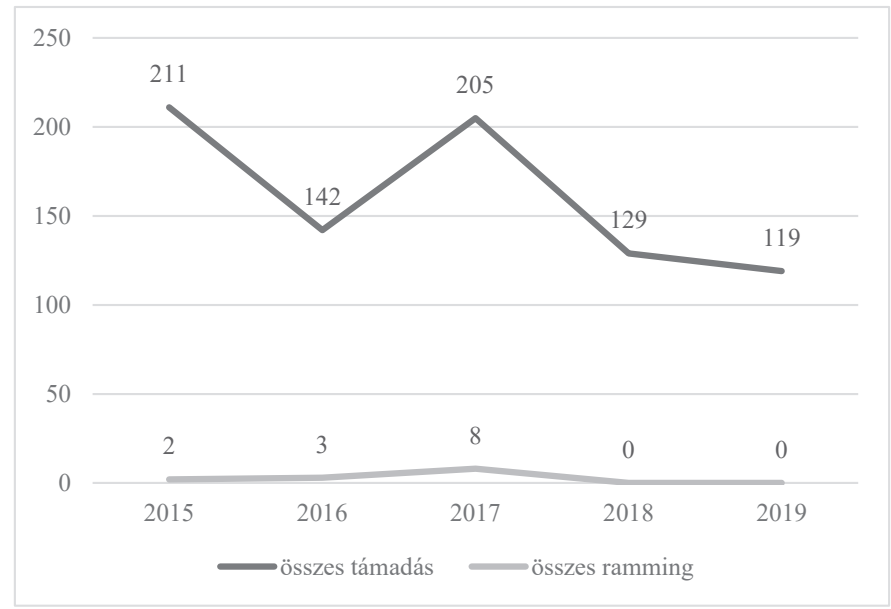

1. ábra: Az EU összes támadásának és ramming támadásainak számát összehasonlitó diagram. Forrás: a szerző szerkesztése

$\mathrm{Az}$ adatok összevetésének lényegét kiemelve egyértelműen elmondható, hogy a vizsgált időszak összesített adataihoz képest a ramming típusú cselekmények száma igen alacsony, ötéves ciklus egyszerú átlagán alapuló arányát tekintve alig több, mint 2\%. Azonban fontos megvizsgálni azt is, hogy a csekély számú jármúvel történő elkövetés mekkora számú természetes személyt érintett közvetlenül, azaz, hogy egy-egy ramming típusú terrortámadás hány személy halálát vagy sérülését eredményezte. Ezt szintén az összes terrorcselekmény halálos áldozatainak, illetve terrorcselekmény során megsérült személyek számának összevetésével tehetjük meg. A terrorizmus körébe vonható bűncselekmények eredményét tekintve a fenti arány már számottevő változást mutat, a 2\%-ot kitevő támadások áldozatainak száma már eléri a 35\%-ot.

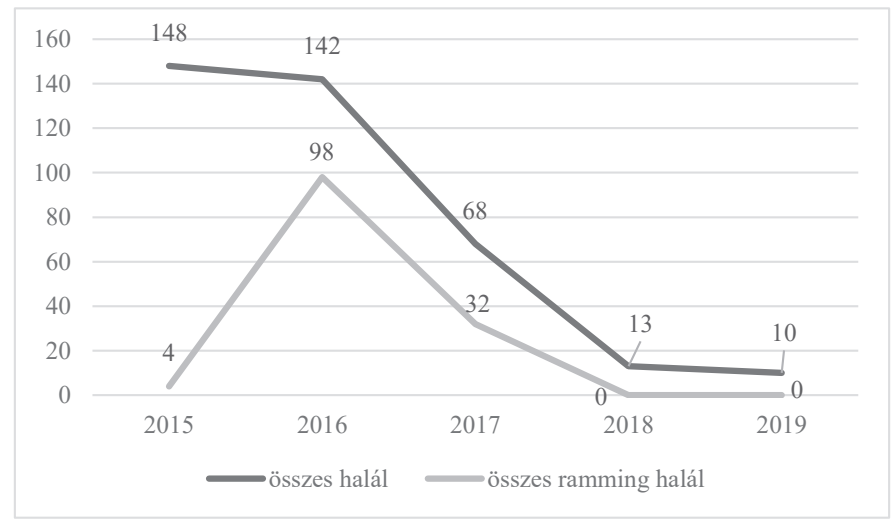

2. ábra: Az EU összes halálos áldozat és ramming halálos áldozat számát összehasonlító diagram. Forrás: a szerző szerkesztése 


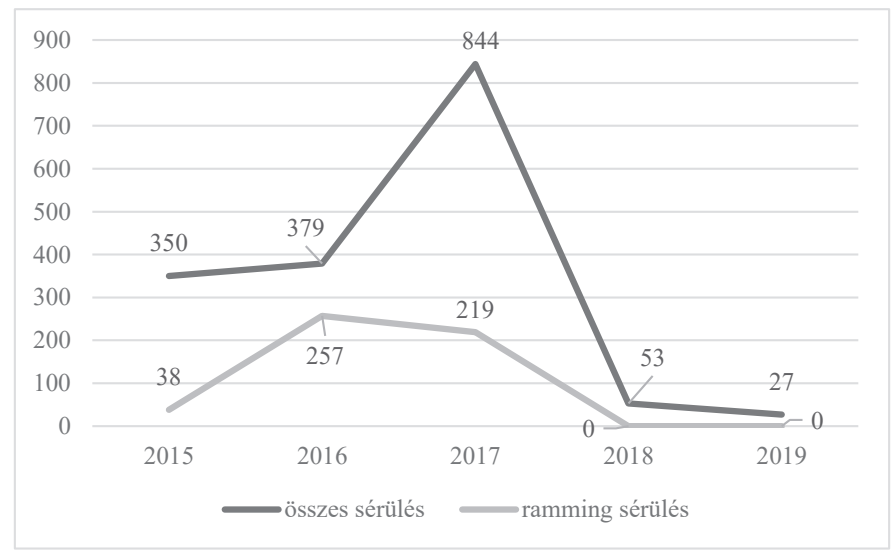

3. ábra: Az EU összes sérült és ramming sérültek számát összehasonlitó diagram. Forrás: a szerzô szerkesztése

Fontos kiemelni azt a tényt is - amelyet egyébként a fenti diagramok is egyértelmúen kimutatnak -, hogy 2016-ban és 2017-ben az EU területén elkövetett terrorcselekmények közül a legtöbb személyt érintő, azaz halálos vagy sérüléses eredménnyel járó támadásokat tömegbe hajtásos módszerrel, tehát az akcióhoz jármúvet eszközként használva követték el.

További összehasonlítást tehetünk, ha megvizsgáljuk a terrortámadás során használt járművek kategóriáját, azaz, hogy személy- vagy teherszállításra alkalmas gépkocsival követték el az adott cselekményt, és ezen adatokhoz hozzávetjük a halálos, illetve sérüléses eredmények számát. Az adatokat megvizsgálva elmondható, hogy a legtöbb halálos áldozatot, illetve a legtöbb személy sérülését okozó ramming típusú támadások esetén a lényegesen nagyobb össztömegủ tehergépkocsik használatát preferálták az elkövetők. A támadásra alkalmas jármú kiválasztásával kapcsolatban egyértelmú következtetéseket nem tudunk levonni arra vonatkozóan, hogy a személy- vagy tehergépkocsik választása volt-e a gyakoribb, hiszen nem áll rendelkezésre elegendő információ, adat az elkövetők aktuális financiális helyzetéről és egyéb személyes kompetenciáiról, amelyek a választásukra nagymértékben hatással vannak. Az viszont egyértelműen kijelenthető, hogy a támadáshoz használt jármű kategóriája jelentős összefüggést mutat a befejezett terrorcselekmények személyeket érintő eredményeivel. Figyelemmel arra, hogy az ilyen jellegű támadások elkövetéséhez gyakorlatilag bármilyen gépjármű igénybe vehető, és ezáltal a terrorizmus alapvető - megfélemlítő, félelmet keltő és a média számottevő érdeklődésével is rendelkező - célja bármelyik gépjárművel elérhető, ezért az ellenük való védekezési lehetőségek körét nem szabad gépjármü-kategóriára leszűkítve vizsgálni. 


\section{Forgalomtechnika mint a védekezés eszköze}

„A forgalomszervezés, más néven forgalomszabályozás vagy forgalomtechnika tudományterülete régebben a teljes közlekedés területén, a különböző közlekedési alágazatokban használatos technikai eszközökre, technológiai megoldásokra értelmezhető volt." ${ }^{15}$ Manapság azonban már a célját megragadva definiálhatjuk a forgalomtechnikát, amelynek „elsődleges célja a közúti forgalom szabályozása, valamint a közlekedőktől elvárt viselkedés meghatározása technikai eszközökön keresztül". ${ }^{16}$ „A forgalomtechnika alapja az út, amihez kapcsolódnak a közúti jelzéseknek nevezett forgalomtechnikai eszközök. Az út kialakítása mellett fontos szerep jut a forgalomirányító fényjelző készülékeknek, a jelzőtábláknak és az útburkolati jelek elhelyezésének. Ez a komplexitás jelenti a közlekedési környezetet." ${ }^{17}$ A vizsgált jelenség szempontjából ezek jellemzőit leginkább úgy tudjuk összefoglalni, hogy mind azt a célt szolgálják, hogy a jármúvet mozgásba hozó vezetô és maga a mozgó jármú is a közúton biztonságosan, a forgalom más résztvevőinek veszélyeztetése nélkül haladjon, közlekedjen. A forgalomtechnikai eszközök egyes csoportjait tekintve a jelzőtáblák és forgalomirányító fényjelző készülékek, valamint az útburkolati jelek jelentősége sem elhanyagolható. Hiszen ezekbe a csoportokba tartozó eszközök feladata a jogszabályi előírások gyakorlati alkalmazásának megteremtése. Különösen fontos szerepet töltenek be egy-egy terület, helyszín közlekedési eszközzel történő elérésében, azaz, hogy a közlekedő személyek és a közlekedési eszközök milyen korlátozások alá eshetnek a haladásuk, közlekedésük során. Értem ezalatt például, hogy bizonyos, akár nagy létszámú tömeg befogadására alkalmas és turisztikailag is frekventált területekre gépjármúvel a behajtás korlátozott, tilalmazott, vagy csak meghatározott irányokból közelíthető meg az adott helyszín. Továbbá a vizsgált téma tükrében, a közlekedési infrastruktúra biztonsága érdekében is megjelenő, a gyalogosokat a gépjármú, illetve egyéb tömegközlekedési forgalomtól fizikailag elválasztó eszközök szerepe is hangsúlyos. Azonban fontos megjegyezni, hogy a közlekedési infrastruktúra szerves részét képező létesítmények épitésénél nem mindig a biztonsági szempontok élveznek előnyt, hanem számos esetben azokat felülírják építéstechnológiai, környezetvédelmi vagy akár kapacitási szempontok. ${ }^{18}$

Jelen tanulmányban ezeket a védelmi lehetőségeket két nagy helyszín köré csoportosítva ismerhetjük meg. Így beszélhetünk a nagyvárosok területén található olyan épületekről, létesítményekről, amelyek akár funkciójuknál fogva, akár turisztikai szempontból bizonyos fokú védelemben részesülnek. Másodsorban pedig azokat a közterületi vagy legalábbis nagy létszámú ember számára nyitva álló hely-

\footnotetext{
Major Róbert (szerk.): Forgalomszervezés és -irányítás. Budapest, Dialóg Campus, 2019. 11.

Major (2019) i. m. 12.

7 Major Róbert: A közúti közlekedési balesetek megelózése, különös tekintettel a rendőrség lehetőségeire és korlátaira. Doktori értekezés. Pécs, Pécsi Tudományegyetem Állam- és Jogtudományi Kar Doktori Iskola, 2009. 99.

18 Lányi Péter: A közúti infrastruktúra biztonsági kezelésének szabályozása. In Koren Csaba (szerk.): Biztonságosabb közúti infrastruktúra. Győr, Universitas-Győr Nonprofit Kft., 2014. 9-18.
} 
színeket szükséges górcső alá venni, amelyek valamilyen tömegrendezvény okán, az eseményeken részt vevők biztonsága érdekében kerülnek ideiglenes védelem alá. Tehát összefoglalva a fixen rögzített, állandóan, hosszabb ideig, folyamatos védelmi funkciót betöltő eszközök, valamint az ideiglenes jelleggel, könnyen mobilizálható eszközök áttekintésére törekszem.

A forgalomtechnika egyéb kellékei között találunk olyan mechanikai és fizikai tulajdonságokkal rendelkező eszközöket, amelyek elsődleges célja a gépjárműforgalom fizikai elválasztása a sérülékenyebb közlekedési résztvevőktől, illetve a mozgásban lévő jármúvek aktuális sebességének csökkentése. Ebbe a körbe sorolhatjuk például az úttestbe épített félgömb formájú, kis és közepes méretű betonelemeket (gömbsüvegkő), a járdákat elkülönítő D-, illetve K-szegélyeket, a sebességcsökkentő küszöböket („fekvőrendőröket”), a sorompókat, különféle oszlopokat, a védőkorlátokat és szalagkorlátokat is. Azonban ezek védelmi képessége nagymértékben függ fizikai és műszaki paramétereiktől, továbbá méretüktől, anyaguktól és rögzítésük módjától is.

Napjainkban már nem csupán a forgalomtechnikai eszközök körébe tartozó védelmi eszközökkel, hanem kifejezetten az építészeti elvárásoknak és trendeknek is megfelelő térelválasztó elemek telepítésével, különféle utcabútorokkal is találkozhatunk egy-egy frekventált helyszín, épület környezetében. A biztonsági szektorban ismeretes a jármúbiztonsági akadály fogalma, amely eszközök elsősorban a katonai alkalmazásból terjedtek át a civil szférába, és már olyan irányvonalat képviselnek, hogy ezek a torlaszok városi vagy lakott környezetbe történő beillesztéssel alkalmassá válnak a járművel történő erőszakos támadások megakadályozására. ${ }^{19}$ A környezetbe történő illeszkedés elvárásának is megfelelve manapság már nagyon sok olyan megoldás is született, amelyek kerülik az elrettentő jelleget, sokkal inkább természetes közegükben elhelyezett közterületi tárgyakként jelennek meg. Ezek lehetnek akár kisebb méretű (például virágláda, pad, szemetestartály) vagy nagyobb terjedelmú (például oszlopok, utcai kandeláberek, magaságyások stb.) akadályok, amelyek védelmet jelenthetnek a becsapódó járművektől. A példálózó jelleggel felsoroltak valódi hatékonysága azonban csak akkor ismerhető el, ha telepítésüket alapos műszaki tervezés, minősítés, különféle tesztek elvégzése és az eszközök ellenőrzése előzte meg, majd beépítésük is megfelelt a rögzítési előírásoknak, szabályoknak. ${ }^{20}$

A nagyvárosok területén található, a járművel történő behatolás, behajtás ellen védett épületek, létesítmények környezetében számos ilyen védelmi eszközt figyelhetünk meg. Ezek közül kiemelendők azok az eszközök, amelyek védelmi funkciója megkérdőjelezhetetlen és a nagyvárosokban már egyértelműen megjelennek. Elsőként a különféle oszlopokat, cölöpöket vizsgálom meg, amelyek szintén két to-

19 Pető Richárd: Sűrűn lakott, forgalmas helyszínek létesítményeinek védelme robbantásos cselekmények ellen. Mũszaki Katonai Közlöny, 23. (2013), 1. 58-68.

20 Szabó Lajos - Balogh Zsuzsanna: A „ramming”, azaz a tömegbe hajtás módszerével elkövetett terrortámadások jelensége és az ellenük való védekezés lehetőségei. Felderítő Szemle, 17. (2018), 4. 140-159. 
vábbi csoportba sorolhatók, azaz a fixen rögzített, tehát csak kifejezett bontási munkálatokat követően eltávolítható, valamint a földbe süllyeszthető, ennélfogva mozgatható oszlopokat. Az első csoportba tartozókra vonatkozóan is ismerünk már külföldi szabványokat, amelyek lehetővé teszik a gépjárművel elkövetett támadások megelőzését, megakadályozását. Egy ilyen szabvány „[á]ltalános eligazítást ad, hogy hogyan alakítsuk ki környezetünket, épületeinket, hogy viszonylagos biztonságban legyünk a bomba- vagy egyéb típusú támadások ellen, ugyanakkor mégse legyen olyan érzetünk, hogy egy katonai erődítményben élünk". ${ }^{21}$

Kiváló hazai például szolgál a főváros szimbolikus jelentőségű belvárosi Kossuth Lajos terének átépítése. Már az átépítés tervezésére vonatkozó pályázati kiírásban ${ }^{22}$ is megjelentek azok a városépítészeti, környezetrendezési, közlekedési és kertépítészeti követelményekkel összhangban álló biztonsági kívánalmak, amelyek az Országház épületének behatolás elleni védelmi szempontjából is kiemelendők. A tervpályázatokat bíráló bizottság már az előzetes bírálati szakaszban követelményként fogalmazta meg, hogy kiemelten foglalkozni kell a térre behajtók fizikai biztosításának elemeivel, valamint a külső biztonsági zónában elvárt, a gépjárművek behajtását akadályozó elemekkel. A rögzített oszlopokat tekintve jelenleg a téren többféle megoldással is találkozhatunk. A leginkább szembetűnő változás mégis a területet korábban északi és déli irányból védeni hivatott vasoszlopok (4. ábra) kiváltása volt az átépítés során, így már két sorban (a sorok között széles zónával) gránittömböket (5. ábra) helyeztek el.

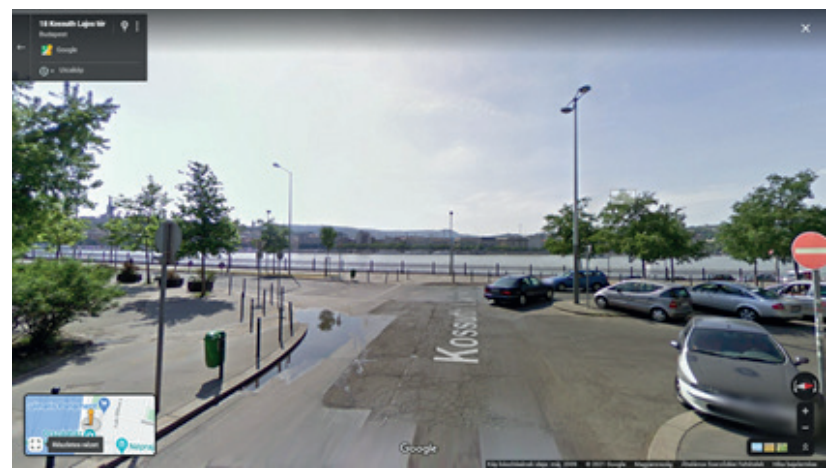

4. ábra: Budapest V. kerület, Kossuth Lajos tér 18. szám utcakép 2009. Forrás: www. google.com/maps

\footnotetext{
Szabó-Balogh (2017) i. m. 144.

Országgyúlés: A tervpályázat tervezési programja. é. n.
} 


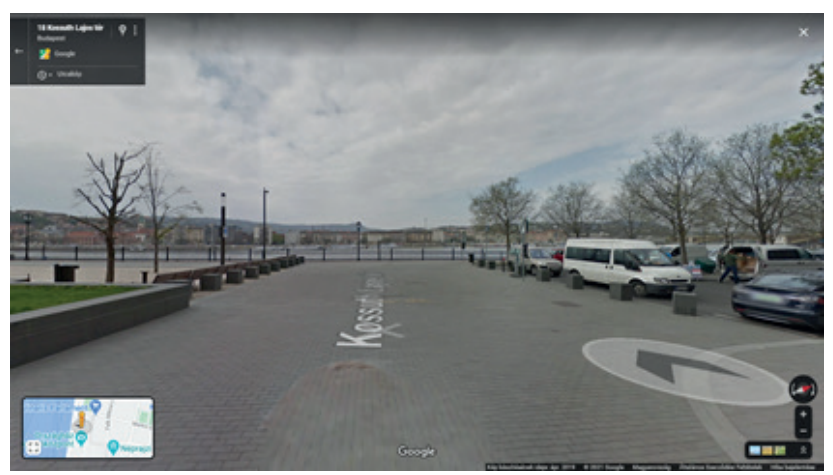

5. ábra: Budapest V. kerület, Kossuth Lajos tér 18. szám utcakép 2019. Forrás: www. google.com/maps

Az aktuális utcaképet mutató 5. ábrán az is jól látható, hogy a védett objektumhoz közelebb eső területen kialakított biztonsági zónába tartozó belső gránittömbsor már egy fokozottabb védelmet biztosító, nemcsak a gépjárművek, hanem az egyéb közlekedési eszközök (kerékpár, segway, roller stb.) és gyalogosok mozgását is akadályozó, szintén gránit szilárdságú térdfalhoz csatlakozik.

A rögzített oszlopok, gránittömbsorok mellett természetesen ezen a helyszínen is megjelennek a mozgatható, azaz a földbe besüllyeszthető oszlopok is. Ezeket összefoglaló közlekedési szakkifejezésként automatizált forgalomkorlátozó oszlopoknak, hétköznapi szóhasználatban pedig süllyedő pollereknek/pilonoknak is nevezzük. Ezen eszközök gyártótól független legfontosabb jellemzői az alábbiak szerint foglalhatók össze:

- anyagukat tekintve változó összetételben, elsősorban ipari acél felhasználásával, azonban mindenképpen kültérre alkalmas, az időjárási viszonyok változásait jól tűrő anyagból és bevonattal készülnek;

- talajszintre süllyeszthetők és onnan kiemelhetők;

- föld alatti méretét az oszlop földfelszíni mérete határozza meg;

- kézi erővel és elektronikus vezérléssel is működtethetők;

- hidraulikus vagy pneumatikus müködési elven alapulnak;

- illetéktelen behajtás vagy parkolás megakadályozását, illetve az átmenő forgalom korlátozását szolgálják;

- a városképhez, a terep esztétikai követelményeihez igazodó, dekoratív és diszkrét külalakkal megtalálhatók a piacon.

Amennyiben a süllyedő pollerek Kossuth Lajos téri alkalmazását tekintjük, akkor egyértelműen kijelenthető, hogy ezen eszközöknek elsősorban a parkolási rend és a jogosultsághoz kötött behajtás szabályozásával, korlátozásával kapcsolatos funkciót használták ki a tér átépítése során. Így ezekkel a védelmi eszközökkel föként a mélygarázsokhoz, parkolókhoz vezető behajtóknál, azaz a kiemelt létesítmé- 
nyek külső védelmi zónájában találkozhatunk. Fontos azonban megjegyezni, hogy a külső védelmi zónában történő elhelyezés ellenére, azért a védelmi jelentőségük nagyon magas szintű, hiszen főként a mélygarázsokba történő illetéktelen gépjárművel behatolás közvetlen utat nyit a védett épületbe történő bejutásra, támadásra is, mivel a mélygarázsok jellemzően közvetlen személyi/gyalogos összeköttetéssel bírnak az objektummal. Így akár lehetőség nyílik a járművel történő támadást követő rövid időn belül az elkövetés eszközének váltására, azaz például egy közvetlenül személyek ellen irányított fegyveres akcióra is. A forgalomtechnikai eszközök másik vizsgálati kategóriája az ideiglenes védelmi eszközöket foglalja magában. $\mathrm{Az}$ állandó védelmi funkciót betöltő eszközökkel ellentétben, ebben a körben már nem találkozhatunk változatos eszközállománnyal. Ennek oka elsősorban az eszközök eltérő fizikai tulajdonságaiban rejlik. Rendőrségi alkalmazásukra a tömegrendezvények szervezői által választott helyszíneken kerül sor, azonban ezen rendezvények többsége nem igényel sajátos létesítményt, kiválasztásuk szempontjai között a szimbolikus jelleg, a hagyományok és kiváltképpen a nagy létszámú befogadóképesség áll. A helyszín kijelölési szempontjai ugyanakkor egyértelműen lehetővé teszik, hogy a közterület fenntartójának hozzájárulásával vagy anélkül is, akár turisztikailag frekventált helyszínt válasszanak a tömegrendezvény színteréül.

További rendészeti felhasználási terület az olyan objektumok, épületek ideiglenes őrzési és védelmi feladatainak ellátása, amely létesítmények korábban nem tartoztak a védetti körbe, és az épület, valamint épített környezete nem felel meg az állandó védelemmel összefüggő biztonsági követelményeknek. Mindezekre figyelemmel a védekezésre, védelemre használható eszközök köre leszűkül, hiszen a hétköznapokban az alkalmazási helyszíneknek nem részük ezek a fizikai akadályok, azokat ideiglenes jelleggel, jól meghatározható időszakokra kell az adott területre telepíteni. Az ideiglenesség pedig egyértelmű elvárást fogalmaz meg az eszközök mobilitásával kapcsolatban, hiszen ebben az esetben rögzítésük sem lehet állandó. Ennek okán a forgalomtechnikai eszközök közül is csak a különösebb beépítési munkálatok nélkül alkalmazható, csekély mértékű telepítést igénylő akadályok állnak a rendészeti szervek rendelkezésére.

A hazai rendészeti gyakorlatban is leggyakrabban alkalmazott forgalomkorlátozó eszköz a folytonos, ugyanakkor különálló New Jersey-elemekből kialakított elválasztó korlát. „Ez a megoldás az acél terelőkorlátokhoz hasonlóan az úton tartást szolgálja, de ellentétben a szalagkorláttal nem, vagy kisebb mértékben rongálódik, illetve nagyobb tömegű vagy mozgási energiájú járművek visszatartására is alkalmas." ${ }^{23}$ A New Jersey-elemeket a talajhoz nem, azonban egymáshoz acélpántok segítségével rögzítik. Amennyiben egymáshoz rögzítés nélkül telepítjük a betonelemeket, abban az esetben kizárólag az egyes elemek saját tömege, míg rögzítéssel a szalagjelleg is visszatartó erőt képvisel. ${ }^{24}$ A betonelemek rendészeti tevékeny-

\footnotetext{
23 Major (szerk.) (2019) i. m. 215.

24 Major (szerk.) (2019) i. m. 215.
} 
ségben történő alkalmazásában a legnagyobb hátrányt az adott helyszínre szállítás és kihelyezés jelenti, hiszen ehhez elegendő számú betonelem rendelkezésre állása, megfelelő szakértelem, illetve szállító- és emelőeszköz szükséges. További hátrányuk az is, hogy formájuknál, külalakjuknál fogva erődemonstrációra kiválóan alkalmasak, ugyanakkor elrejtésükre, épített környezetbe való beillesztésükre nem ismertek kreatív, de a biztonsági tulajdonságokat nem módosító megoldások. A hazai rendészeti gyakorlatban ezeket az eszközöket 2015 óta alkalmazzák a fővárosi tömegrendezvények rendőri biztosításánál, a Budapesti Rendőr-főkapitányság biztosítási tevékenységében időről időre - a terrorveszélyeztetettség szintjétől függően - megjelennek az egyedi festéssel ellátott New Jersey-elemek (6. ábra). A tengeren túli rendészeti alkalmazásban a zsilipszerủ elhelyezéssel szemben a gyalogos áthaladást biztosító rést hagyó párhuzamos kihelyezési gyakorlat is preferált.

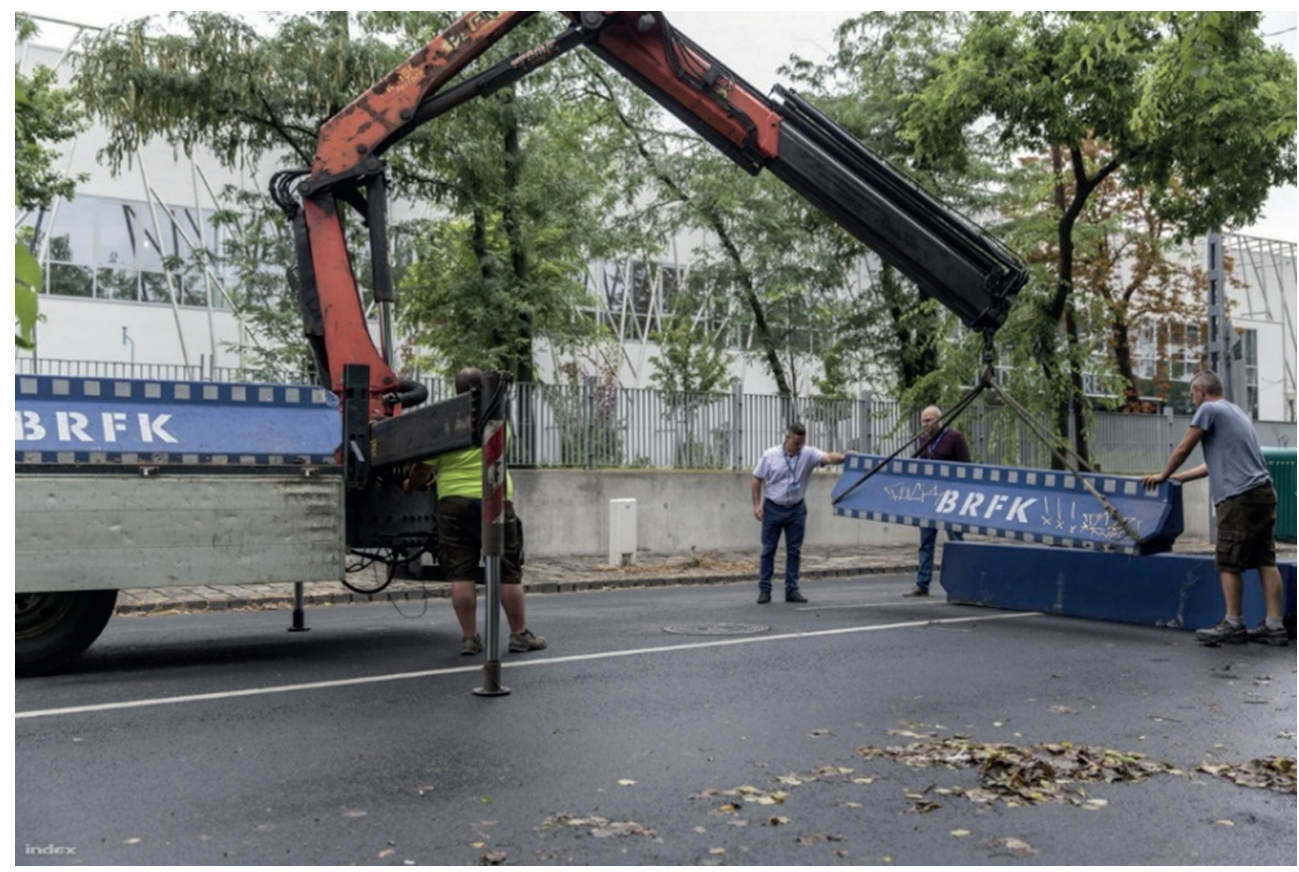

6. ábra: New Jersey-elemek kihelyezése 15. Európai Maccabi Játékok biztositása, Budapest Ludovika Campus, 2019. július 29. Forrás: Jávor Bence: Szigorú sportértéke nincs sok, ez inkább egy fesztivál. Index, 2019.

A fent leírt mobilizálható védelmi elemek rendészeti célú alkalmazásában rejlő problémák orvoslása nemcsak hazánkban várat még magára, mindezidáig nemzetközi viszonylatban sem sikerült mind a biztonsági, mind az esztétikai követelményeket kielégítő megoldásokat felkutatni. Ugyanakkor a kihívások kezelésére, a hátrányok kiküszöbölésére akadnak már jó gyakorlatok. Személyes megfigyelésen alapuló tapasztalataim bizonyítják, hogy Európa más országaiban a New Jersey-elemek al- 
kalmazása nem kizárólagos, például a bajor rendészeti szervek hatékonyan alkalmaznak más forgalomtechnikai eszközöket is. Hasonlóan a minden évben turisták tömegét vonzó fővárosi Vörösmarty téren megtartott karácsonyi vásárhoz, a szintén tekintélyes hagyományokkal bíró nürnbergi Christkindlesmarkt védelméről is gondoskodnak a rendőri szervek. Továbbá a 2016-os berlini terrortámadást követően a németországi nagyvárosok adventi helyszíneinek ramming akciókkal szembeni védelme érdekében már díszletnek álcázott, tehát a karácsonyi ünnepi helyszínbe illeszkedő és a látogatók szubjektív biztonságérzetét szinte észrevétlenül pozitív irányba befolyásoló biztonsági eszközöket (7. ábra) is bevetnek.

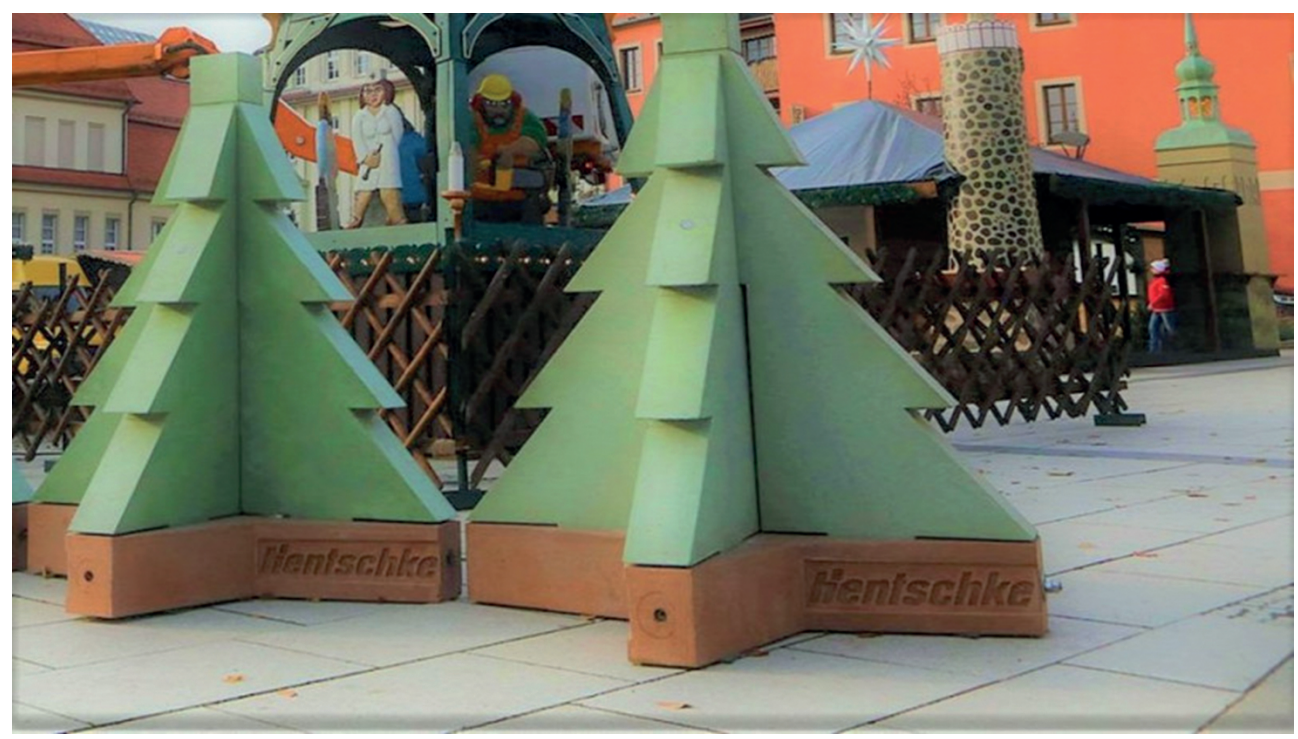

7. ábra: Fenyőfa formájú betonelemek Németországban. Forrás: Ismét biztonsági óvintézkedések közepette nyitnak a karácsonyi vásárok Németországban. Origo, 2019.

\section{5. Összegzés}

Napjainkban a terrorizmus továbbra is veszélyforrást jelent az EU tagállamainak biztonságára, azonban Magyarország terrorveszélyeztetettsége közepes szintűnek mondható, azaz a fenyegetettség szintje alacsonyabb, mint más tagállamokban. Figyelemmel arra, hogy hazánk turisztikai szempontból fesztivál-nagyhatalomnak számít, ezért a tömegrendezvények ramming típusú támadásokkal szembeni kitettsége továbbra sem vitatható. Fontos továbbá hangsúlyozni, hogy nemcsak a nagy számú résztvevőt vonzó kulturális események, politikai demonstrációk, hanem a nemzetközi sportrendezvények is célponként jelenhetnek meg, így a terrorelhárítási, valamint a rendészeti szerveknek is folyamatosan ezen események és látogatóik személyi biztonsága ellen intézett támadásokkal szembeni hatékony 
védekezésre kell törekedni. Az alapvető intézkedéseket többek között át kell hogy hassák a biztonságtechnikai, épületvédelmi, várostervezési és városépítészeti, valamint a forgalomszabályozási elvek is. Kiemelendő továbbá a megújulási hajlam fejlesztése is, amelyet a vizsgált témában elsősorban hazai és külföldi gyakorlati szakemberek, illetve elméleti kutatók munkájának összefogásával fokozni lehet. A láthatatlan ellenség elleni küzdelem együttes összefogással, a gyakorlati tapasztalatok és a gondolati tőke összeadásával a ma még kihívást jelentő kérdésekre megoldásokkal szolgálhatnak. Az előre megjósolhatatlan eseményekre, támadásokra pontos, ellenőrzött információk hiányában teljes mértékben felkészülni ugyan nem tudunk, ugyanakkor a védekezési lehetőségek folyamatos elemzésével, hatékonyságuk növelésével, az eszközök biztonsági fejlesztésével az alapvető felkészülési feladatok teljesíthetők.

\section{IRODALOMJEGYZÉK}

Boda József (főszerk.): Rendészettudományi szaklexikon. Budapest, Dialóg Campus, 2019.

Europol: EU Terrorism Situation \& Trend Report (TE-SAT) Reviewing the terrorism phenomenon. 2020. Online: www.europol.europa.eu/activities-services/main-reports/eu-terrorism-situation-and-trend-report

Fehér Zoltán: Gondolatok az aszimmetrikus rendészeti kihívásokról és a lehetséges válaszokról. Hadtudomány, (2015), 1-2. 130-135. Online: https://doi.org/10.17047/ HADTUD.2015.25.1-2.72

Kasza Anett: A fővárosi metró alkalmazási lehetőségei a tömegrendezvények biztosítása során. Katasztrófavédelmi Szemle, 19. (2012), 4. 23-27.

Lányi Péter: A közúti infrastruktúra biztonsági kezelésének szabályozása. In Koren Csaba (szerk.): Biztonságosabb közúti infrastruktúra. Győr, Universitas-Győr Nonprofit Kft., 2014.

Lippai Zsolt - Thieme-Eső Milán: A szállodák, mint „puha célpontok” In Közös kihívások - egykor és most: Tanulmánykötet. Budapest, Magyar Rendészettudományi Társaság Vám- és Pénzügyőri Tagozat, 2020. 160-183. Online: https://doi.org/10.37372/mrttvpt.2020.1.9

Major Róbert: A közúti közlekedési balesetek megelözése, különös tekintettel a rendörség lehetőségeire és korlátaira. Doktori értekezés. Pécs, Pécsi Tudományegyetem Állam- és Jogtudományi Kar Doktori Iskola, 2009.

Major Róbert (szerk.): Forgalomszervezés és -irányítás. Budapest, Dialóg Campus, 2019.

Pető Richárd: Sưrűn lakott, forgalmas helyszínek létesítményeinek védelme robbantásos cselekmények ellen. Müszaki Katonai Közlöny, 23. (2013), 1. 58-68.

Rácz András - Brestyánszki Flóra: A gépjárművel végrehajtott, ramming típusú terrortámadásokról és a védekezés lehetőségeiről. Nemzet és Biztonság, (2017), 5. 61-69.

Szabó Lajos - Balogh Zsuzsanna: A „ramming”, azaz a tömegbe hajtás módszerével elkövetett terrortámadások jelensége és az ellenük való védekezés lehetőségei. Felderítő Szemle, 17. (2018), 4. 140-159.

\section{Jogi forrás}

1/1975. (II. 5.) KPM-BM együttes rendelet a közúti közlekedés szabályairól 


\section{Internetes források}

Budapest V. kerület, Kossuth Lajos tér 18. szám utcakép 2009. és 2019. Online: www.google.com/ maps

Heves Megyei Kormányhivatal Rendvédelmi Igazgatás tájékoztató felülete: Közbiztonság, tömegkezelés. tájékoztató prezentáció. Online: www.kormanyhivatal.hu/download/4/10/ c5000/5_K\%C3\%B6zbiztons\%C3\%A1g\%20t\%C3\%B6megkezel\%C3\%A9s.pdf

Jávor Bence: Szigorú sportértéke nincs sok, ez inkább egy fesztivál. Index, 2019. Online: https:// index.hu/sport/2019/07/31/zsido_olimpia_2019_emg_europai_maccabi_jatekok/

Ismét biztonsági óvintézkedések közepette nyitnak a karácsonyi vásárok Németországban. Origo, 2019. Online: www.origo.hu/nagyvilag/20191126-ismet-biztonsagi-ovintezkedesek-kozepette-nyitnak-a-karacsonyi-vasarok-nemetorszagban.html

Országgyülés: A tervpályázat tervezési programja. é. n. Online: www.parlament.hu/documents/10181/20791/kossuth_ter_4m.pdf/3888f29a-81a7-4139-88e5-ac3a17925a8a

\section{ABSTRACT}

\section{The Role of Traffic Technology in Large Cities in the Fight against Terrorism Erika GÁL}

The study primarily examines the connections between the means of metropolitan road transport and traffic engineering, as well as the terrorist acts committed with a road vehicle. In addition to the basic definitions, the study examines the tools of traffic technology, which are also functional in the fight against terrorism from two perspectives: on the one hand, from the point of view of priority and permanently protected objects and on the other hand, from places temporarily protected in large cities. In order to be able to categorise each type of vehicle, European statistics on vehicle types and fatalities in recent years will also be processed. After scientific research, the study makes an attempt to formulate professional placement proposals for traffic engineering devices that take into account both law enforcement and architectural aspects.

Keywords: road vehicles, tools of traffic organising, street furniture, mobile physical barrier, terrorist acts, object protection, mass events, security operation 